\title{
An Analysis of the Multi-Cultural Characteristics of the Pre-Service Teachers in Terms of the Values They Have
}

\author{
Suat POLAT ${ }^{1}$ \\ 'A $\breve{g r}$ İbrahim Çeçen University, Education Faculty, Department of Social Sciences Education, Ağrr-Turkey \\ Email:suat.polato4@yandex.com
}

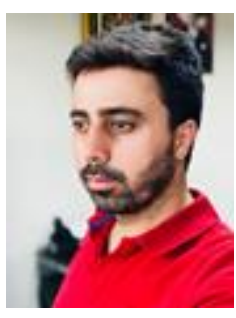

\begin{abstract}
In this study, it was aimed to analyze the multi-cultural characteristics of the pre-service teachers and the values they have in terms of various variables, and it was aimed to determine the relationship between these values. Descriptive survey model, one of the quantitative research methods, was used in the study. The population of the study consisted of the pre-service teachers studying in different departments in the Faculty of Education, İbrahim Çeçen University of Ağrı in 2017-2018 academic years. The sample of the study consisted of 341 pre-service teachers selected with random sampling method. "Multicultural Personality Questionnaire" developed by Oudenhoven and Zee (2002) and adapted into Turkish by Polat (2009) and "Values Scale" developed by Dilmac et al. (2014) were used as data collection tool in the study. According to the results obtained from the study, it was determined that the value preferences of the pre-service teachers and their multicultural personality characteristics showed a significant difference in terms of gender, undergraduate program, educational background of the mother, having social media account and daily internet use variables; however, there was not a significant difference in terms of family structure, the place s/he grew up, educational background of the father and monthly income variables. As the data collection tools are formed of several sub-dimensions, the abstract does not include information about which groups are favored for the difference in the variables and in which sub-dimensions, but detailed information is given in the following sections of the study.
\end{abstract}

Keywords: Multiculturalism, Value, Teacher candidates, Culture.

Citation | Suat POLAT (2018). An Analysis of the Multi-Cultural Characteristics of the Pre-Service Teachers in Terms of the Values They Have. Asian Journal of Education and Training, 4(4): 325-335. History:

Received: 3 July 2018

Revised: 14 August 2018

Accepted: 10 September 2018

Published: 24 September 2018

Licensed: This work is licensed under a Creative Commons

Attribution 3.0 License (cc)

Publisher:Asian Online Journal Publishing Group
Funding: This study received no specific financial support.

Competing Interests: The author declares that there are no conflicts of interests regarding the publication of this paper.

Transparency: The author confirms that the manuscript is an honest, accurate, and transparent account of the study was reported; that no vital features of the study have been omitted; and that any discrepancies from the study as planned have been explained.

Ethical: This study follows all ethical practices during writing.

\section{Contents}

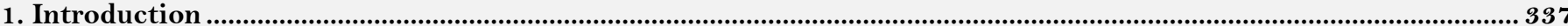

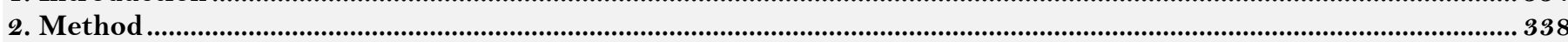

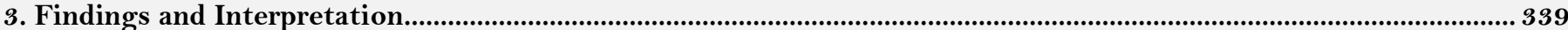

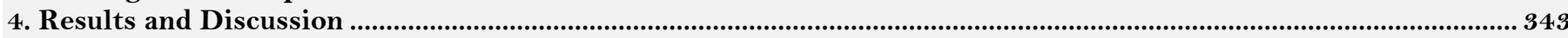

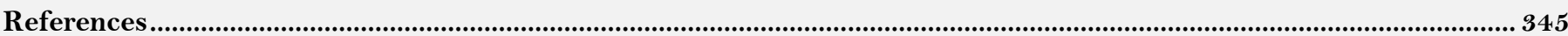




\section{Introduction}

Culture, which determines the identity of a society and makes it different from other societies, is a concept that is studied a lot and with different approaches. This concept has found its place in every process from the day when human beings exist to today (Özhan, 2006).

Culture, in general, consists of abstract ideas, values and world-oriented perceptions that inform us about the behavior of people and take part in these behaviors. All these elements are shared by the members of the society and creates behavior patterns that can only be understood by the members of that society (Binat, 1971; Turhan, 1972; Güngör, 1978; Güvenç, 2010) as cited in Ünlü and Örten (2013). These behavior patterns have social characteristics and they are adopted by the members that forms the society. All these behavior patterns in the societies have caused different societies to know to knit up with each other and the cultures to influence each other as a result of the developing and changing world conditions. This process has occurred rather because people immigrate to other societies, and because of communities that are formed with economic, social, etc. relations (Cirık, 2008). This cultural interaction created a new perception along with itself during the socialization. This perception has gained importance as "multiculturalism", that is, societies know each other without losing their essence (Fergeson, 2008) as cited in Ünlü and Örten (2013).

The multiculturalism term first appeared in USA in the world. It is known that the United States, along with geographical discoveries, has hosted many people of different nations within it. With the intensive migration to the USA, the gathering of people of different cultures has made multiculturalism inevitable. In the 1960s, the concept of multiculturalism in the United States in the 1970s started to make itself felt fully due to the rise of different cultures, the spread of ideas such as human rights and democracy, the desire of women, ethnic groups for equal rights and freedom and the discrimination of racism and sexism (Başbay and Bektaş, 2009).

In the concept of multiculturalism, each culture is valuable, and the comparison between cultures is not right, besides, every culture should evaluate its truths within its own framework. It is the basic philosophical source of multiculturalism that the values that cultures have should not necessarily be compared with the values and norms of other cultures, and that they are accepted as a value on their own (Özensel, 2012).

The values of the people can affect their multicultural personality characteristics. Values are important cultural items that all human beings need to have for as they give meaning to mankind, provide to be respectful to other people, to respect differences, to keep societies alive and to ensure societies live long. There is no single definition of the concept of value, and a wide variety of descriptions have been made in this regard.

Value is "The abstract measure that determines the importance of something, the response that something costs, is the whole of the material and spiritual items that encompass the social, cultural, economic and scientific values of a nation" (www.tdk.gov.tr).

Education plays an important role in bringing the values system about the frame of mind of a certain society into individuals. Schools, on the other hand, are very important institutions for socializing and bringing values to individuals. Among the important tasks of the schools is to teach everything that constitutes culture and value to the students according to the curriculum specified. It is among the other duties of the school to discipline pupils in accordance with certain rules, to contribute to their moral development and to improve their character positively (Ercan, 2001).

Multicultural education, on the other hand, is an approach that requires multicultural politics to take place in education. The goal of multicultural education, in general, has been to reduce inequality to a minimum level, to provide equality of opportunities and chances in education. Another goal of multicultural education is to reconstruct the schools and the education system and to teach the students how to treat the people in different societies (Yazıcı et al., 2009). Teachers undertake the greatest role in bringing important events such as multiculturalism and values to students in our education system.

Teachers are at the forefront as the most important factor in achieving the desired goal and ensuring the desired productivity in multicultural education. Especially in societies where multicultural education finds itself in a new debate, teachers have a position to play a critical role. At this point, as a result of the education received by the pre-service teachers, students are required to produce behavioral patterns appropriate for the profession in the cognitive, emotional and psychomotor fields and to develop their students. Another target for teachers to achieve success is to respect the cultural differences of their students and create a democratic learning environment (Ünlü and Örten, 2013).

It is possible to list the aims of multicultural education as follows;

- To bring a secure, embracing and successful learning environment for students,

- To reinforce the different things about global issues,

- To strengthen cultural consciousness,

- To reinforce the knowledge of culturally differentiation,

- To make students realize that there are multiple historical perspectives,

- To make critical thinking and thinking effective.

When the literature is reviewed, it is possible to find various studies related to multiculturalism (Curık, 2008; Başbay and Bektaş, 2009; Polat, 2009; Yazıcı et al., 2009; Polat and Kılıç, 2013; Ünlü and Örten, 2013; Bulut and Başbay, 2014; Sarıçam, 2014; Akhan and Yalçın, 2016) and values (Bacanlı, 1999; Ercan, 2001; Yapıcı and Zengin, 2003; Sarı, 2005; Aktay and Ekşi, 2009; Deveci and Selanik, 2009; Yilmaz, 2009; Balcı and Yelken, 2010; Yiğittir and Öcal, 2011; Akkaya, 2013; Balcı and Yelken, 2013; Cengelci et al., 2013; Mutlu and Öztürk, 2017). Studies in the literature generally consist of studies that take one-sided examination of multiculturalism and values preferences. This study is important from the point of view of an important deficiency in the field by examining the pre-service teachers' multicultural characteristics according to the values they have.

\subsection{Purpose}

The purpose of this study is to examine the values of the multi-cultural personality traits of pre-service teachers. 


\subsection{Research Problem}

Examination of pre-service teachers' multicultural personality traits and value preferences in terms of various variables and determination of the relationship between them.

\subsection{Sub-Problems}

- Does the multicultural personality traits and value preferences of pre-service teachers differ significantly according to gender?

- Does the multicultural personality traits and value preferences of pre-service teachers differ significantly according to undergraduate program?

- Does the multicultural personality traits and value preferences of pre-service teachers differ significantly according to the place they have grown up?

- Does the multicultural personality traits and value preferences of pre-service teachers differ significantly according to family structure?

- Does the multicultural personality traits and value preferences of pre-service teachers differ significantly according to the education status of mother?

- Does the multicultural personality traits and value preferences of pre-service teachers differ significantly according to the education status of father?

- Does the multicultural personality traits and value preferences of pre-service teachers differ significantly according to the monthly income of the family?

- Does the multicultural personality traits and value preferences of pre-service teachers differ significantly according to daily internet use?

- Does the multicultural personality traits and value preferences of pre-service teachers differ significantly according to whether they have a social media account or not?

\section{Method}

This study is designed based on the quantitative research approach. Quantitative research is the kind of research which advocates that reality exists on its own in nature, apart from the researcher, and that this reality can be observed, measured and analyzed in an objective way. Such research is based on the hypothesis that reality and feelings must be separated from each other. In quantitative research, variables can be clearly separated from each other and the relationships between them can be measured. At the same time, generalizations can be made with the results obtained. According to this research method, reality is concrete objects that we realize with five sense organs (Yıldırım and Şimşek, 2008; Büyüköztürk et al., 2014; Sonmez and Alacapınar, 2014).

Descriptive survey model, among quantitative research methods, was used in the study. In descriptive survey research, data related to more than one fact can be collected and relations between these facts can be analyzed (Can, 2014). The relationship revealed in such studies indicates that a part of the change in one of the variables may be caused by another variable, but it also indicates that this change cannot be interpreted in terms of the cause-effect relationship between the variables (as cited in, Can (2014)). This research model aims to determine the presence or degree of change existing between two or more variables (as cited in Köse (2015)).

\subsection{Population and Sample}

The population of the study consists of pre-service teachers studying in the Faculty of Education, İbrahim Çeçen University of Ağrı in 2017-2018 academic years. The sample of the study consists of 341 pre-service teachers from different undergraduate programs. In the selection of the pre-service teachers to be included in the sample, random sampling method, one of the probability sampling methods, was used. In this method of sampling, each individual in the population has the same chance and probabilities to be selected for sample. Individuals who are thought to have certain characteristics are selected randomly for the sample (Yıldırım and Şimşek, 2008). In this sampling method, the unit selection process is usually performed by the method of drawing lots from the population. After the population list is created, each group is given a sequence number and they are included in the sampling by drawing random numbers. Numbers in lot are included in drawing lot again to equalize the selection possibilities of each unit in the population (Can, 2014).

\subsection{Data Collection Tools}

The "Multicultural Personality Questionnaire" developed by Oudenhoven and Zee (2002) and adapted to Turkish by Polat (2009) and "Value Scale" developed by Dilmac et al. (2014) were used to collect data in the study.

Multicultural Personality Questionnaire is a 5-likert-tyoe scale and consists of 33 items, and consists of dimensions, 11 of which measures cultural empathy, 6 of which measures social enterprise, 7 of which measures emotional stability, 5 of which measures openness and 4 of which measures flexibility. The reliability coefficient of the whole of the "Multicultural Personality Questionnaire" was found to be .82 by Polat (2009) the reliability coefficients of the sub-dimensions were calculated as .87 for social empathy, .73 for social enterprise, .65 for emotional stability, .66 for openness and .67 for flexibility.

Cronbach alpha internal consistency coefficients of Value Scale developed by Dilmac et al. (2014) were also calculated on a factor basis. As a result of the analysis, the Cronbach alpha internal consistency coefficient is .90 for "Social Values", .80 for "Career Values", .78 for "Intellectual Values", 78 for "Spirituality", 78 for "Materialist Values" 61 for "Human Dignity", .66 for "Romantic Values", .65 for "Liberty" and .63 for "Generosity".

\subsection{Data Collection}

The data of the study were collected in the spring term of 2017-2018 academic years. "Multicultural Personality Questionnaire" developed by Oudenhoven and Zee (2002) and adopted into Turkish by Polat (2009) and "Values Scale" developed by Dilmac et al. (2014) were applied on a volunteer basis to the pre-service teachers 
included in the study who were selected randomly. A 30-minute time was given to the pre-service teachers to fill the data collection tools. During this time, appropriate feedback was given to the questions asked by the pre-service teachers to maintain a healthy data collection process.

\subsection{Data Analysis}

Independent samples t-test, MANOVA and Pearson correlation were used for the parametric tests because normality assumption was satisfied in the analysis of the data. The significance of the data was tested at $\mathrm{p}<.01$ and $\mathrm{p}<.05$ level.

\section{Findings and Interpretation}

This section includes the findings and interpretations related to the analyses on the variables of gender, department, family structure, the place they have grown up, educational status of mother and father, monthly income, having a social media account and daily internet use in terms of multicultural personality traits and the values of the pre-service teachers. The results of the analysis of the value preferences and multicultural personality traits of teacher candidates in terms of gender variable are indicated in Table 1.

Table-1. Independent Sample t Test Results related to the Gender Variable

\begin{tabular}{|c|c|c|c|c|c|c|}
\hline & Gender & $\bar{n}$ & $\bar{x}$ & $\overline{\text { S.S }}$ & $t$ & $\bar{p}$ \\
\hline \multirow[t]{2}{*}{ Social Value } & Female & 190 & 8.212 & .825 & \multirow[t]{2}{*}{1.268} & \multirow[t]{2}{*}{.206} \\
\hline & Male & 151 & 8.102 & .772 & & \\
\hline \multirow[t]{2}{*}{ Career Value } & Female & 190 & 7.577 & 1.049 & \multirow[t]{2}{*}{.888} & \multirow[t]{2}{*}{.375} \\
\hline & Male & 151 & 7.474 & 1.098 & & \\
\hline \multirow[t]{2}{*}{ Intellectual Value } & Female & 190 & 7.921 & .888 & \multirow[t]{2}{*}{.920} & \multirow[t]{2}{*}{.358} \\
\hline & Male & 151 & 7.828 & .956 & & \\
\hline \multirow[t]{2}{*}{ Spirituality } & Female & 190 & 7.801 & 1.419 & \multirow[t]{2}{*}{4.968} & \multirow[t]{2}{*}{.000} \\
\hline & Male & 151 & 6.880 & 1.997 & & \\
\hline \multirow[t]{2}{*}{ Materialistic Value } & Female & 190 & 6.147 & 1.891 & \multirow[t]{2}{*}{.650} & \multirow[t]{2}{*}{.516} \\
\hline & Male & 151 & 6.004 & 2.164 & & \\
\hline \multirow[t]{2}{*}{ Human Dignity } & Female & 190 & 8.414 & .912 & \multirow[t]{2}{*}{-1.183} & \multirow[t]{2}{*}{.238} \\
\hline & Male & 151 & 8.529 & .877 & & \\
\hline \multirow[t]{2}{*}{ Romantic Value } & Female & 190 & 5.705 & 2.255 & \multirow[t]{2}{*}{-3.949} & \multirow[t]{2}{*}{.000} \\
\hline & Male & 151 & 6.624 & 1.974 & & \\
\hline \multirow[t]{2}{*}{ Liberty } & Female & 190 & 8.022 & .795 & \multirow[t]{2}{*}{-.747} & \multirow[t]{2}{*}{.455} \\
\hline & Male & 151 & 8.094 & .986 & & \\
\hline \multirow[t]{2}{*}{ Generosity } & Female & 190 & 7.586 & 1.297 & \multirow[t]{2}{*}{-2.024} & \multirow[t]{2}{*}{.044} \\
\hline & Male & 151 & 7.867 & 1.239 & & \\
\hline \multirow[t]{2}{*}{ Cultural Empathy } & Female & 190 & 4.149 & .589 & \multirow[t]{2}{*}{.926} & \multirow[t]{2}{*}{.355} \\
\hline & Male & 151 & 4.091 & .549 & & \\
\hline \multirow[t]{2}{*}{ Social Enterprise } & Female & 190 & 3.441 & .694 & -1.137 & .256 \\
\hline & Male & 151 & 3.523 & .605 & & \\
\hline Emotional Stability & Female & 190 & 3.153 & .569 & -.753 & .452 \\
\hline & Male & 151 & 3.200 & .581 & & \\
\hline Openness & Female & 190 & 3.661 & .673 & -2.002 & .046 \\
\hline & Male & 151 & 3.800 & .587 & & \\
\hline Flexibility & Female & 190 & 3.551 & .808 & 2.758 & .006 \\
\hline & Male & 151 & 3.314 & .760 & & \\
\hline
\end{tabular}

Source: Author's field work.

When Table 1 is analyzed, it is seen that as a result of the $t$ test done to determine whether there is significant difference in terms of gender variable in the values and multicultural personality traits of the teachers, there is significant difference between the averages of the sub-dimensions of spirituality, romantic value, generosity, openness and flexibility. It was determined that the females have higher averages in terms of the values in the spirituality sub-dimension in the values of the pre-service teachers, and the males have higher averages in terms of the values in the romantic value sub-dimension. It was also determined that the males have higher averages in the openness sub-dimension, and females have higher averages in the flexibility sub-dimension when the multicultural personality traits of the per-service teachers were analyzed.

The results of the analysis of the value preferences and multicultural personality traits of teacher candidates in terms of undergraduate program variable are indicated in Table 2. 
Table-2. One-Way MANOVA Results related to the Undergraduate Program Variable

\begin{tabular}{|c|c|c|c|c|c|c|c|}
\hline & Dependent Variable & Average Total & sd & Average Square & $\mathbf{F}$ & $\mathbf{P}$ & nsquare \\
\hline \multirow{14}{*}{$\begin{array}{l}\text { Undergraduate } \\
\text { Program }\end{array}$} & Social Value & 2,140 & $5-341$ &, 428 & ,660 & 654 & .010 \\
\hline & Career Value & 18,813 & $5-341$ & 3,763 & 3,396 & ,006 & .048 \\
\hline & Intellectual Value & 2,448 & $5-341$ & ,490 &, 576 & ,718 & .009 \\
\hline & Spirituality & 26,460 & $5-341$ & 5,292 & 1,731 &, 127 & .025 \\
\hline & Materialistic Value & 28,982 & $5-341$ & 5,796 & 1,437 &, 211 & .021 \\
\hline & Human Dignity & 5,541 & $5-341$ & 1,108 & 1,382 & ,230 & .020 \\
\hline & Romantic Value & 16,038 & $5-341$ & 3,208 & ,671 & ,646 & .010 \\
\hline & Liberty & 4,117 & $5-341$ &, 823 & 1,053 & ,387 & .015 \\
\hline & Generosity & 10,026 & $5-341$ & 2,005 & 1,232 & ,294 & .018 \\
\hline & Cultural Empathy & 3,291 & $5-341$ & ,658 & 2,043 &, 072 & .030 \\
\hline & Social Enterprise & 6,135 & $5-341$ & 1,227 & 2,922 & ,013 & .042 \\
\hline & Emotional Stability & 3,239 & $5-341$ & ,648 & 1,994 & ,079 & .029 \\
\hline & Openness & 2,454 & $5-341$ & ,491 & 1,204 &, 307 & .018 \\
\hline & Flexibility & 14,596 & $5-341$ & 2,919 & 4,884 & ,000 & .068 \\
\hline
\end{tabular}

Source: Author has calculated by using primary data.

When Table 2 is examined, one-way multivariate analysis was conducted to determine the effect of the undergraduate program variable on multicultural personality traits and value preferences of the pre-service teachers, when the counts of the MANOVA analysis were checked, it was found that the homogeneity count of the diffusion matrix is provided according to Box's M statistic. $(\mathrm{F}(525,785.18)=1.327, \mathrm{p}=.061)$.

A significant difference was found only in the career value sub-dimension in terms of the value preferences of the pre-service teachers in terms of undergraduate program. As a result of the TUKEY test to find the source of the difference, it was determined that the pre-service teacher studying in Music-Art undergraduate program (8.069) attach more importance to career value compared to those in the Social Sciences (7.433), Preschool (7.334) and Psychological Counseling and Guidance (7.349) undergraduate programs.

It was determined that there is significant difference in the social enterprise and flexibility sub-dimensions from the multicultural personality traits of the pre-service teachers in terms of undergraduate program (Wilks Lambda $=.0413, \quad \mathrm{~F}(5-337)=2.922, \quad \mathrm{p}<.05, \quad$ nsquare $=.042 ;$ Wilks Lambda $=.0468, \mathrm{~F}(5-337)=4.884, \quad \mathrm{p}<.05$, nsquare=.068). Multiple comparison tests were conducted to determine the source of this difference in the social enterprise and flexibility sub-dimensions in terms of the undergraduate program variable. According to the findings of the TUKEY test, it was determined that the pre-service teachers studying in Preschool undergraduate program (3.703) have higher social enterprise than those in Classroom Teaching program (3.307), and the flexibility of the pre-service teachers in Preschool undergraduate program (3.75) is higher than those in Social Sciences (3.265), Turkish Language (3.25) and Music-Art (3.293) undergraduate programs.

The results of the analysis related to the family structure variable in terms of value preferences and multicultural personality traits of the pre-service teachers are indicated in Table 3.

Table-3. One-Way MANOVA Results related to Family Structure Variable

\begin{tabular}{|c|c|c|c|c|c|c|c|}
\hline & Dependent Variable & Average Total & sd & Average Square & $\mathbf{F}$ & $\mathbf{P}$ & nsquare \\
\hline \multirow{14}{*}{$\begin{array}{l}\text { Family } \\
\text { Structure }\end{array}$} & Social Value &, 010 & $2-341$ & ,005 & ,007 & ,993 &, 000 \\
\hline & Career Value & 1,609 & $2-341$ &, 805 &, 700 & 497 & ,004 \\
\hline & Intellectual Value & 2,438 & $2-341$ & 1,219 & 1,448 & ,236 & ,008 \\
\hline & Spirituality & 8,595 & $2-341$ & 4,298 & 1,394 & ,249 & ,008 \\
\hline & Materialistic Value & 9,598 & $2-341$ & 4,799 & 1,183 & ,308 & ,007 \\
\hline & Human Dignity & 2,509 & $2-341$ & 1,254 & 1,561 &, 211 & ,009 \\
\hline & Romantic Value & 6,415 & $2-341$ & 3,208 & ,673 &, 511 & ,004 \\
\hline & Liberty & 1,590 & $2-341$ & ,795 & 1,016 & ,363 & ,006 \\
\hline & Generosity & 7,513 & $2-341$ & 3,756 & 2,318 &, 100 & , 014 \\
\hline & Cultural Empathy &, 165 & $2-341$ & ,083 &, 251 &, 778 & ,001 \\
\hline & Social Enterprise & 2,247 & $2-341$ & 1,123 & 2,626 & ,074 &, 015 \\
\hline & Emotional Stability & 1,774 & $2-341$ &, 887 & 2,719 & ,067 & ,016 \\
\hline & Openness & 1,479 & $2-341$ &, 740 & 1,817 &, 164 & ,011 \\
\hline & Flexibility & 905 & $2-341$ & ,453 &, 715 & 490 & ,004 \\
\hline
\end{tabular}

Source: Author has calculated by using primary data.

When Table 3 is examined, one-way multivariate analysis was conducted to determine the effect of the family structure variable on multicultural personality traits and value preferences of the pre-service teachers, it was found that the homogeneity count of the diffusion matrix is provided according to Box's M statistic when the counts of the MANOVA analysis were examined $(\mathrm{F}(210,397.481)=1.400, \mathrm{p}=.059)$.

When the MANOVA results are examined, it is seen that there is no significant difference in terms of family structure variable in value preferences and multicultural personality traits of the pre-service teachers. Therefore, it can be said that family structure variable is not a factor that affects the value preferences and personality traits of the pre-service teachers.

The results of the analysis related to the place they grew up variable in terms of value preferences and multicultural personality traits of the pre-service teachers are indicated in Table 4. 
Table-4. One-Way MANOVA Results related to The Place They Grew up Variable

\begin{tabular}{|c|c|c|c|c|c|c|c|}
\hline & Dependent Variable & Average Total & sd & Average Square & $\mathbf{F}$ & $\mathbf{P}$ & nsquare \\
\hline \multirow{14}{*}{$\begin{array}{l}\text { The Place they } \\
\text { grew up }\end{array}$} & Social Value & ,939 & $3-341$ & ,313 & ,483 & 694 & ,004 \\
\hline & Career Value & 1,999 & $3-341$ & ,666 &, 579 & ,629 & ,005 \\
\hline & Intellectual Value &, 207 & $3-341$ & ,069 & ,081 & ,970 & ,001 \\
\hline & Spirituality & 4,980 & $3-341$ & 1,660 &, 535 & ,659 & ,005 \\
\hline & Materialistic Value & 24,406 & $3-341$ & 8,135 & 2,021 &, 111 & ,018 \\
\hline & Human Dignity &, 317 & $3-341$ &, 106 &, 130 & ,942 & ,001 \\
\hline & Romantic Value & 2,581 & $3-341$ &, 860 &, 180 & ,910 & ,002 \\
\hline & Liberty & ,399 & $3-341$ & , 133 &, 169 & ,918 & ,001 \\
\hline & Generosity & 1,468 & $3-341$ & ,489 & ,298 &, 827 & ,003 \\
\hline & Cultural Empathy & 1,363 & $3-341$ & 454 & 1,393 & ,245 & ,012 \\
\hline & Social Enterprise & 1,662 & $3-341$ & ,554 & 1,286 & ,279 & ,011 \\
\hline & Emotional Stability &, 236 & $3-341$ & , 079 &, 237 &, 870 & ,002 \\
\hline & Openness & 1,884 & $3-341$ & ,628 & 1,543 & ,203 &, 014 \\
\hline & Flexibility & 2,608 & $3-341$ & ,869 & 1,380 & ,249 & ,012 \\
\hline
\end{tabular}

When Table 4 is examined, one-way multivariate analysis was conducted to determine the effect of the place they grew up variable on multicultural personality traits and value preferences of the pre-service teachers, it was found that the homogeneity count of the diffusion matrix is provided according to Box's M statistic when the counts of the MANOVA analysis were checked $(\mathrm{F}(315,440.930)=1.239, \mathrm{p}=.131)$.

When the MANOVA results are examined, it is seen that there is no significant difference in terms of the place they grew up variable in value preferences and multicultural personality traits of the pre-service teachers. Therefore, it can be said that the place they grew-up variable is not a factor that affects the value preferences and personality traits of the pre-service teachers.

The results of the analysis related to the educational background of the father variable in terms of value preferences and multicultural personality traits of the pre-service teachers are indicated in Table 5 .

Table-5. One-Way MANOVA Results related to Educational Background of the Father Variable

\begin{tabular}{|c|c|c|c|c|c|c|c|}
\hline & Dependent Variable & Average Total & sd & Average Square & $\mathbf{F}$ & $\mathbf{P}$ & nsquare \\
\hline \multirow{14}{*}{$\begin{array}{l}\text { Educational } \\
\text { Background of } \\
\text { the Father }\end{array}$} & Social Value & 1,756 & $5-341$ & ,351 &, 541 &, 745 & ,008 \\
\hline & Career Value & 2,740 & $5-341$ &, 548 &, 474 & ,796 &, 007 \\
\hline & Intellectual Value & 1,259 & $5-341$ &, 252 & ,295 &, 915 & ,004 \\
\hline & Spirituality & 8,984 & $5-341$ & 1,797 &, 578 &, 717 & ,009 \\
\hline & Materialistic Value & 20,513 & $5-341$ & 4,103 & 1,010 & 411 &, 015 \\
\hline & Human Dignity & 1,311 & $5-341$ & ,262 & ,322 &, 900 & ,005 \\
\hline & Romantic Value & 39,051 & $5-341$ & 7,810 & 1,658 &, 144 &, 024 \\
\hline & Liberty & 2,049 & $5-341$ & $4+10$ &, 520 & ,761 & ,008 \\
\hline & Generosity & 2,578 & $5-341$ &, 516 & ,313 &, 905 & ,005 \\
\hline & Cultural Empathy & 1,124 & $5-341$ &, 225 & ,684 & ,636 & ,010 \\
\hline & Social Enterprise & 4,263 & $5-341$ & ,853 & 2,004 &, 078 & ,029 \\
\hline & Emotional Stability & 1,204 & $5-341$ & ,241 &, 727 & ,603 & ,011 \\
\hline & Openness & 2,626 & $5-341$ &, 525 & 1,289 & ,268 & ,019 \\
\hline & Flexibility & 4,454 & $5-341$ & 891 & 1,418 &, 217 &, 021 \\
\hline
\end{tabular}

Source: Author has calculated by using primary data.

When Table 5 is examined, one-way multivariate analysis was conducted to determine the effect of the educational background of the father variable on multicultural personality traits and value preferences of the preservice teachers, it was found that the homogeneity count of the diffusion matrix is provided according to Box's M statistic when the counts of the MANOVA analysis were checked $(F(525,696.139)=1.163, p=.061)$.

When the MANOVA results are examined, it is seen that there is no significant difference in terms of the educational background of the father variable in value preferences and multicultural personality traits of the preservice teachers. Therefore, it can be said that the educational background of the father variable is not a factor that affects the value preferences and personality traits of the pre-service teachers.

The results of the analysis related to the educational background of the mother variable in terms of value preferences and multicultural personality traits of the pre-service teachers are indicated in Table 6.

Table-6. One-Way MANOVA Results related to Educational Background of the Mother Variable

\begin{tabular}{|c|c|c|c|c|c|c|c|}
\hline & Dependent Variable & Average Total & sd & Average Square & $\mathbf{F}$ & $\mathbf{P}$ & nsquare \\
\hline \multirow{14}{*}{$\begin{array}{l}\text { Educational } \\
\text { Background } \\
\text { of the Mother }\end{array}$} & Social Value & 1,715 & $5-341$ & 429 & ,662 & ,619 & ,008 \\
\hline & Career Value & 2,725 & $5-341$ & ,681 &, 591 & ,669 & ,007 \\
\hline & Intellectual Value & 2,492 & $5-341$ & ,623 & ,736 & ,568 & ,009 \\
\hline & Spirituality & 36,101 & $5-341$ & 9,025 & 2,989 & ,019 & ,034 \\
\hline & Materialistic Value & 22,094 & $5-341$ & 5,523 & 1,366 & ,245 & ,016 \\
\hline & Human Dignity & ,681 & $5-341$ &, 170 & ,209 & ,933 & ,002 \\
\hline & Romantic Value & 19,072 & $5-341$ & 4,768 & 1,002 & ,406 & ,012 \\
\hline & Liberty & 1,951 & $5-341$ & 488 & ,621 & ,648 & ,007 \\
\hline & Generosity & 8,640 & $5-341$ & 2,160 & 1,328 & ,259 & ,016 \\
\hline & Cultural Empathy & 1,479 & $5-341$ &, 370 & 1,132 & , 341 & ,013 \\
\hline & Social Enterprise & 1,346 & $5-341$ & ,337 &, 777 &, 541 & ,009 \\
\hline & Emotional Stability & 1,303 & $5-341$ & ,326 & ,989 & 414 & ,012 \\
\hline & Openness &, 561 & $5-341$ &, 140 &, 340 &, 851 & ,004 \\
\hline & Flexibility & ,923 & $5-341$ & ,231 & ,363 & ,835 & ,004 \\
\hline
\end{tabular}

Source: Author has calculated by using primary data. 
When Table 6 is examined, one-way multivariate analysis was conducted to determine the effect of the educational background of the mother variable on multicultural personality traits and value preferences of the preservice teachers, it was found that the homogeneity count of the diffusion matrix is provided according to Box's M statistic when the counts of the MANOVA analysis were checked $(\mathrm{F}(420,603.356)=1.200, \mathrm{p}=.055)$.

When the MANOVA results are examined, it can be seen that there is significant difference in spirituality subdimensions of the value preferences in terms of the educational background of the mother variable (Wilks Lambda $=.0397, \mathrm{~F}(5-341)=2.922, \mathrm{p}<05$, nsquare $=.034)$.

TUKEY test, among multiple comparison tests, was conducted to determine the source of the differentiation in the spirituality sub-dimension in terms of the educational background of the mother. As a result of TUKEY test, it can be said that the spirituality values of the pre-service teachers whose mothers are illiterate (7.47) and primary school graduate (7.65) are higher than those whose mothers got high school or higher education (6.36).

The results of the analysis related to the monthly income variable in terms of value preferences and multicultural personality traits of the pre-service teachers are indicated in Table 7 .

Table-7. One-Way MANOVA Results related to Monthly Income Variable

\begin{tabular}{|c|c|c|c|c|c|c|c|}
\hline & Dependent Variable & Average Total & sd & Average Square & $\mathbf{F}$ & $\mathbf{P}$ & nsquare \\
\hline \multirow{14}{*}{ Monthly Income } & Social Value & 1,068 & $2-341$ &, 534 & ,827 & 438 &, 005 \\
\hline & Career Value & 1,094 & $2-341$ &, 547 & ,476 & ,622 & ,003 \\
\hline & Intellectual Value & 3,194 & $2-341$ & 1,597 & 1,902 &, 151 & 011 \\
\hline & Spirituality & 6,823 & $2-341$ & 3,412 & 1,105 & ,332 & ,006 \\
\hline & Materialistic Value & 3,429 & $2-341$ & 1,714 & 421 &, 657 & ,002 \\
\hline & Human Dignity & ,959 & $2-341$ & 479 & ,593 &, 553 & ,003 \\
\hline & Romantic Value & 7,383 & $2-341$ & 3,691 &, 775 & ,462 & ,005 \\
\hline & Liberty & 3,308 & $2-341$ & 1,654 & 2,127 &, 121 & ,012 \\
\hline & Generosity & 7,349 & $2-341$ & 3,675 & 2,267 &, 105 & ,013 \\
\hline & Cultural Empathy & ,933 & $2-341$ & ,466 & 1,430 &, 241 & ,008 \\
\hline & Social Enterprise & ,596 & $2-341$ & ,298 & 689 &, 503 & ,004 \\
\hline & Emotional Stability & ,631 & $2-341$ &, 315 & 957 & ,385 & ,006 \\
\hline & Openness &, 525 & $2-341$ &, 263 & ,641 &, 528 & ,004 \\
\hline & Flexibility & ,709 & $2-341$ &, 355 &, 560 &, 572 & ,003 \\
\hline
\end{tabular}

Source: Author has calculated by using primary data.

When Table 7 is examined, one-way multivariate analysis was conducted to determine the effect of the monthly income variable on multicultural personality traits and value preferences of the pre-service teachers, it was found that the homogeneity count of the diffusion matrix is provided according to Box's M statistic when the counts of the MANOVA analysis were checked $(\mathrm{F}(210,511.879)=1.170, \mathrm{p}=.073)$.

When the MANOVA results are examined, it is seen that there is no significant difference in terms of the monthly income variable in value preferences and multicultural personality traits of the pre-service teachers. Therefore, it can be said that the monthly income variable is not a factor that affects the value preferences and personality traits of the pre-service teachers.

The results of the analysis related to the having a social media account variable in terms of value preferences and multicultural personality traits of the pre-service teachers are indicated in Table 8.

Table-8. One-Way MANOVA Results related to Having a Social Media Account Variable

\begin{tabular}{|c|c|c|c|c|c|c|c|}
\hline & Dependent Variable & Average Total & sd & Average Square & $\mathbf{F}$ & $\bar{P}$ & $\overline{\text { nsquare }}$ \\
\hline \multirow{14}{*}{$\begin{array}{l}\text { Having a Social } \\
\text { Media Account }\end{array}$} & Social Value &, 155 & $1-341$ &, 155 &, 240 & ,625 &, 001 \\
\hline & Career Value &, 188 & $1-341$ &, 188 &, 164 & ,686 & ,OOO \\
\hline & Intellectual Value &, 275 & $1-341$ &, 275 & ,325 &, 569 & ,001 \\
\hline & Spirituality & 4,462 & $1-341$ & 4,462 & 1,446 & ,230 & ,004 \\
\hline & Materialistic Value &, 826 & $1-341$ & ,826 & ,203 & ,653 & ,001 \\
\hline & Human Dignity &, 317 & $1-341$ & ,317 & ,392 &, 532 & ,001 \\
\hline & Romantic Value & 5,682 & $1-341$ & 5,682 & 1,195 &, 275 & ,004 \\
\hline & Liberty & 1,512 & $1-341$ & 1,512 & 1,937 &, 165 & ,006 \\
\hline & Generosity & 3,952 & $1-341$ & 3,952 & 2,430 &, 120 & ,007 \\
\hline & Cultural Empathy & ,204 & $1-341$ & ,204 &, 624 & ,430 & ,002 \\
\hline & Social Enterprise &, 028 & $1-341$ & ,028 & ,065 & ,798 & ,OOO \\
\hline & Emotional Stability & ,090 & $1-341$ & ,090 & ,271 & ,603 & ,001 \\
\hline & Openness & ,058 & $1-341$ & ,058 &, 141 & ,708 & ,OOO \\
\hline & Flexibility & 3,227 & $1-341$ & 3,227 & 5,169 & ,024 & 015 \\
\hline
\end{tabular}

Source: Author has calculated by using primary data.

When Table 8 is examined, one-way multivariate analysis was conducted to determine the effect of the having a social media account variable on multicultural personality traits and value preferences of the pre-service teachers, it was found that the homogeneity count of the diffusion matrix is provided according to Box's M statistic when the counts of the MANOVA analysis were checked $(\mathrm{F}(105,160.029)=1.376, \mathrm{p}=.07)$.

When the MANOVA results are examined, it is seen that there is significant difference in terms of the having a social media account variable in flexibility sub-dimension of multicultural personality traits of the pre-service teachers (Wilks Lambda $=.0170, \mathrm{~F}(1-341)=5.169, \mathrm{p}<.05$, nsquare $=.015)$. As a result, it can be said that the preservice teachers who have a social media account (3.488) are more flexible compared to those who don't (3.222) in terms of flexibility-sub-dimension.

The results of the analysis related to the daily internet use variable in terms of value preferences and multicultural personality traits of the pre-service teachers are indicated in Table 9. 
Table-9. One-Way MANOVA Results related to Daily Internet Use Variable

\begin{tabular}{|c|c|c|c|c|c|c|c|}
\hline & Dependent Variable & Average Total & sd & Average Square & $\mathbf{F}$ & $\mathbf{P}$ & nsquare \\
\hline \multirow{14}{*}{$\begin{array}{l}\text { Daily Internet } \\
\text { Use }\end{array}$} & Social Value & 3,311 & $3-341$ & 1,104 & 1,722 & , 162 &, 015 \\
\hline & Career Value & 3,151 & $3-341$ & 1,050 & 915 &, 434 & ,008 \\
\hline & Intellectual Value & 5,306 & $3-341$ & 1,769 & 2,116 & ,098 & ,018 \\
\hline & Spirituality & 23,602 & $3-341$ & 7,867 & 2,582 & ,053 &, 022 \\
\hline & Materialistic Value & 41,936 & $3-341$ & 13,979 & 3,519 &, 015 & ,030 \\
\hline & Human Dignity & ,731 & $3-341$ &, 244 & ,300 &, 825 & ,003 \\
\hline & Romantic Value & 19,026 & $3-341$ & 6,342 & 1,337 & ,262 &, 012 \\
\hline & Liberty & 1,351 & $3-341$ & 450 &, 573 & ,633 & ,005 \\
\hline & Generosity & 6,047 & $3-341$ & 2,016 & 1,237 & ,296 &, 011 \\
\hline & Cultural Empathy &, 513 & $3-341$ &, 171 &, 521 & ,668 & ,005 \\
\hline & Social Enterprise & 1,407 & $3-341$ & ,469 & 1,087 & ,355 & ,010 \\
\hline & Emotional Stability & 3,046 & $3-341$ & 1,015 & 3,139 & ,026 &, 027 \\
\hline & Openness & 2,726 & $3-341$ & ,909 & 2,246 & ,083 &, 020 \\
\hline & Flexibility & 4,116 & $3-341$ & 1,372 & 2,194 & ,089 & 019 \\
\hline
\end{tabular}

Source: Author has calculated by using primary data.

When Table 9 is examined, one-way multivariate analysis was conducted to determine the effect of the daily internet use variable on multicultural personality traits and value preferences of the pre-service teachers, it was found that the homogeneity count of the diffusion matrix is provided according to Box's M statistic when the counts of the MANOVA analysis were checked $(\mathrm{F}(315,414.062)=1.202, \mathrm{p}=.08)$.

When the MANOVA results are examined, it can be seen that there is significant difference in materialistic value sub-dimension of value preferences and emotional stability sub-dimension of multicultural personality traits of the pre-service teachers in terms of daily internet use variable (Wilks Lambda $=.05, \mathrm{~F}(3-341)=3.519, \mathrm{p}<.05$, nsquare=.030; Wilks Lambda $=.05, \mathrm{~F}(3-341)=3.139$, $\mathrm{p}<.05$, nsquare $=.027)$.

TUKEY test was applied to determine the source of the difference in the materialistic value and emotional stability sub-dimensions in terms of daily internet use variable. As a result of the test, it was determined that the pre-service teachers who use internet for 6 hours or more (6.55) have higher materialistic values than those who use $0-2$ hours (5.67), and the average points of the pre-service teacher who use the internet for 0-2 hours (3.283) are higher than those who use the internet for 4-6 hours (3.005) in terms of emotional stability.

The results related to the relationship between the value preferences and multicultural personality traits of the pre-service teachers are indicated in Table 10.

Table-10. Analysis of the Relationship between Value Preferences and Multicultural Personality Traits

\begin{tabular}{|c|c|c|c|c|c|c|c|c|c|c|}
\hline & & Social & Career & Intellectual & Spirituality & Materialistic & $\begin{array}{l}\text { Human } \\
\text { Dignity }\end{array}$ & Romantic & Liberty & Generosity \\
\hline \multirow{3}{*}{$\begin{array}{l}\text { Cultural } \\
\text { Empathy }\end{array}$} & Pearson &, $342^{* * 4}$ &, $114^{*}$ & $176^{* * *}$ & ,092 &,- 006 & ,089 & 087 &, $213^{* *}$ & ,204** \\
\hline & Sig. (2-tailed) &, 000 & ,036 &, 001 &, 088 &, 909 &, 101 &, 108 &, 000 &, 000 \\
\hline & $\mathrm{N}$ & 341 & 341 & 341 & 341 & 341 & 341 & 341 & 341 & 341 \\
\hline \multirow{3}{*}{$\begin{array}{c}\text { Social } \\
\text { Enterprise }\end{array}$} & Pearson &, 039 &, 064 & ,094 &,- 071 &, 094 &,- 053 &, $240^{* *}$ & ,139* & ,093 \\
\hline & Sig. (2-tailed) & 476 &, 238 &, 082 & 193 & ,084 & ,329 &, 000 &, 010 &, 085 \\
\hline & $\mathrm{N}$ & 341 & 341 & 341 & 341 & 341 & 341 & 341 & 341 & 341 \\
\hline \multirow{3}{*}{$\begin{array}{l}\text { Emotional } \\
\text { Stability }\end{array}$} & Pearson & 058 &,- 019 &,- 014 &, 012 &,$- 150^{* * *}$ &,- 002 &, 008 &, 027 & 079 \\
\hline & Sig. (2-tailed) &, 283 &, 724 &, 795 &, 824 &, 005 &, 973 &, 876 &, 617 &, 146 \\
\hline & $\mathrm{N}$ & 341 & 341 & 341 & 341 & 341 & 341 & 341 & 341 & 341 \\
\hline \multirow[t]{3}{*}{ Openness } & Pearson &, 097 &, $116^{*}$ &, $128^{*}$ &,- 032 &, $175^{* *}$ &,- 037 &, $145^{* *}$ &, $212^{* *}$ &, $188^{* * *}$ \\
\hline & Sig. (2-tailed) &, 075 & ,032 & ,018 &, 560 & ,001 &, 498 &, 007 &, 000 & , \\
\hline & $\mathrm{N}$ & 341 & 341 & 341 & 341 & 341 & 341 & 341 & 341 & 341 \\
\hline \multirow[t]{3}{*}{ Flexibility } & Pearson &, 026 &,- 093 &,$- 117^{*}$ &,- 017 &,- 013 &,- 013 &, 073 & ,019 &,- 024 \\
\hline & Sig. (2-tailed) &, 626 & ,087 & ,030 &, 755 & 814 & 805 &, 178 &, 724 &, 655 \\
\hline & $\mathrm{N}$ & 341 & 341 & 341 & 341 & 341 & 341 & 341 & 341 & 341 \\
\hline
\end{tabular}

When Table 10 is analyzed, it is seen that according to Pearson's correlation analysis results, there is a positive and medium-level relationship between cultural empathy and social value, there is a positive and weak-level relationship between intellectual value and generosity, there is a positive and weak-level relationship between social enterprise, liberty and romantic value, a negative and weak level relationship between emotional stability and materialistic value, a positive and weak-level relationship between openness and materialistic value, romantic value, liberty and generosity.

According to this result, it can be said that people with cultural empathy personality trait can give higher importance to social, intellectual, liberty and generosity values. It can be said that people with social enterprise personality trait can give more importance to the romantic values. It can be expressed that people with emotional stability personality trait can give less importance to the materialistic values. However, people with openness personality trait can give more importance to the materialistic values. People with openness personality trait give more importance to the romantic, liberty and generosity values.

\section{Results and Discussion}

In this study which aims to analyze the multicultural personality traits of the pre-service teachers in terms of value preference, the data obtained through multicultural personality questionnaire and values scale were analyzed in terms of various variables and the obtained results are presented in this section of the study.

The value preferences and multicultural personality traits of the pre-service teachers were analyzed in terms of gender variable, and it was determined that there is a significant difference between the average scores in the spirituality, romantic value, generosity, openness and flexibility sub-dimensions. In the value preferences of the 
pre-service teachers, females have higher average scores in terms of the values in the spirituality sub-dimension, and males have higher average scores in terms of the values in the romantic value sub-dimension. Moreover, when the multicultural personality traits of the pre-service teachers were examined, it was determined that males have higher average scores in the openness sub-dimension and females have higher average scores in the flexibility subdimension.

In a study conducted by Demircioğlu and Özdemir (2014) it was determined that the attitudes of the preservice teachers towards the multicultural education differ significantly according to the gender, and this difference was found to be in favor of the female participants. Although the significance values were not examined in the study conducted by Damgacı and Aydın (2013) it was determined that academicians' attitude scores related to multicultural education were higher in favor of female academicians. Demir (2012) found that the importance that female academicians give to multicultural education in equalitarian pedagogy sub-dimension was significantly more positive compared to male academicians. Contrary to these studies, it was determined in the studies by Tortop (2014); Özdemir and Dil (2013) that the attitudes of pre-service teachers and teachers towards multicultural education did not differ in terms of gender. In the study conducted by Polat (2012) it was determined that the attitudes of school principals towards multiculturalism did not differ according to gender. In another study conducted by Polat (2009) no significant relation was found between the gender of pre-service teachers and their multicultural personality traits. In the study conducted by Yapıcı and Zengin (2003) it was emphasized that there was no significant difference in the value preferences of the pre-service teachers in the Faculty of Theology in terms of gender variable.

In another study conducted by Sarı (2005) the levels of the male students in terms of adopting values were significantly higher in all values (public moral, political, religious, economic, aesthetic, social values) except for scientific value compared to those of the female students. In the study conducted by Başçiftçi et al. (2011) it is seen that male students in the values of hedonism, ability and effort of value judgments had significantly higher average scores, and female students have significantly higher average scores in universality, helpfulness and accord subdimensions. In another study conducted by Bacanlı (1999) it has been found that female students paid more attention to universal, liberty and peace values, whereas male students attach more importance to devotion to traditions and religious values. In the study conducted by Akkaya (2013) it was determined that the female preservice teachers had significantly higher scores in the values of everything is measured and accord and conscious peace, and the male pre-service teachers had significantly higher average scores in terms of earning the heaven, knowing the facts and fighting for liberty values. Aktay and Ekşi (2009) stated in their study that female teachers were more likely to prefer self-control value, male teacher were more likely to prefer universality value, and that there was no difference in other values. In the study conducted by Yilmaz (2009) it was concluded that the average score of female teachers in terms of universality, helpfulness, accord and security sub-dimensions was significantly higher than male teachers.

The value preferences of the pre-service teachers were examined in terms of the undergraduate program and significant difference was found only in the career value sub-dimension. According to this difference, the preservice teacher studying in Music-Art undergraduate program (8.069) attach more importance to career value compared to those in the Social Sciences (7.433), Preschool (7.334) and Psychological Counseling and Guidance (7.349) undergraduate programs.

A significant difference was also found in the social enterprise and flexibility sub-dimensions of the pre-service teachers in terms of the undergraduate program variable.

It can be said that the pre-service teachers studying in Preschool undergraduate program (3.703) have higherlevel of social enterprise than those in Classroom Teaching program (3.307), and the flexibility level of the preservice teachers in Preschool undergraduate program (3.75) is higher than those in Social Sciences (3.265), Turkish Language (3.25) and Music-Art (3.293) undergraduate programs. According to this result, it can be said that the education and practices that the preschool pre-service teachers get during their undergraduate education positively affect their social enterprise and flexibility traits. In the study by Demircioğlu and Özdemir (2014) it was found that there is a significant difference between multicultural education and student attitudes. But the fact that this difference is in favor of non-math fields contradicts the results of this study. In the study carried out by Polat (2009) a significant difference was found in the cultural empathy sub-dimension of the multicultural personality traits of the teacher candidates and the undergraduate program. In the study by Akkaya (2013) it was determined that there is a significant difference in favor of Mathematics Teaching department in terms of the values of everything is measured and accord and comfortable life, in favor of Classroom Teaching department in terms of earning the heaven value, in favor of Turkish Language Teaching department in terms of a world without lies value, and in favor of Religious Culture Teaching department in terms of conscious peace, ensuring equality, helping people values. Contrary to these studies, it has been determined in the study conducted by Tortop (2014) that the attitudes of pre-service teachers towards multicultural education did not differ in terms of the undergraduate program variable.

The value preferences and multicultural personality traits of the pre-service teachers were examined in terms of family structure, the place they grew up, educational background of father and monthly income variables, and no significant difference was found between them. Therefore, it can be said that family structure, the place they grew up, educational background of father and monthly income variables are not factors that affect the value preferences and multicultural personality traits of the pre-service teachers. Tortop (2014) reached the conclusion in his study that there is no significant difference between the income status and multicultural education. In the study by Demircioğlu and Özdemir (2014) the attitudes of the pedagogical formation training students towards multicultural education did not show any significant difference according to the place they grew up. In the study conducted by Polat (2009) no significant relation was found between the place where the pre-service teachers lived and their multicultural personality traits.

In the study by Akkaya (2013) it was determined that there is an inversely proportional relation between educational background of father variable and redemption value, however there is a directly proportional relation between educational background of father variable and living a comfortable life value. In the same study by Akkaya 
(2013) it was determined that in terms of the place they grew up variable, those who live in big cities have significantly higher average scores in comfortable life and fight for liberty values compared to those who live in small cities.

The value preferences of the pre-service teachers were examined according to the education background of the mother and a significant difference was found in the spirituality sub- dimension. According to the difference in educational background of mother in the spirituality sub-dimension, it can be said that the spirituality values of the pre-service teachers whose mothers are illiterate (7.47) and primary school graduate (7.65) are higher than those whose mothers got high school or higher education (6.36). According to this result, it can be interpreted that the increase of the education level of the mothers negatively affects the spirituality value preferences of the children. It can be said that mothers with lower education level give more importance to spiritual values. In the study by Akkaya (2013) it was found that the children of mothers with low or no education levels had a significantly higher average score for the values in the earning the heaven sub-dimension, which is parallel to the findings of this study.

It was determined that there is significant difference in terms of the having a social media account variable in flexibility sub-dimension of multicultural personality traits of the pre-service teachers. It can be said that the preservice teachers who have a social media account (3.488) are more flexible compared to those who don't (3.222) in terms of flexibility-sub-dimension. Therefore, it can be said that the use of social media has a positive effect on the flexibility personality trait.

It was determined that there is a significant difference in the materialistic value of the value preferences of the pre-service teachers, and there is a significant difference in the emotional stability of multicultural personality traits in terms of daily internet use variable.

According to the difference in materialistic value and emotional stability sub-dimensions, it is seen that the preservice teachers who use internet for 6 hours or more (6.55) have higher materialistic values than those who use $0-$ 2 hours (5.67), and the average points of the pre-service teacher who use the internet for 0-2 hours (3.283) are higher than those who use the internet for 4-6 hours (3.005) in terms of emotional stability. According to this result, it can be said that more internet use leads to an increase in materialistic value preferences of the pre-service teachers while it causes decrease in emotional stability. Moreover, it can be said that the pre-service teachers with high emotional stability have lower materialistic value priorities.

The relationship between the sub-dimensions of multicultural personality questionnaire and values scale was examined and the results are as follows: there is a positive and medium-level relationship between cultural empathy and social value, there is a positive and weak-level relationship between intellectual value and generosity, there is a positive and weak-level relationship between social enterprise, liberty and romantic value, a negative and weak level relationship between emotional stability and materialistic value, a positive and weak-level relationship between openness and materialistic value, romantic value, liberty and generosity.

According to this result, it can be said that the importance that the individuals with cultural empathy personality trait give to social, intellectual, liberty and generosity values may be higher. It can also be said that the importance that the individuals with social enterprise personality trait give to romantic values may increase. It can be stated that the individuals with higher emotional stability personality traits give less importance to the materialistic values. However, the individuals with openness personality characteristics give higher importance to the materialistic values. The individuals with openness personality trait give more importance to the romantic, liberty and generosity values.

According to Büyüköztürk (2004) the correlation coefficient can be interpreted as an absolute value and between 0.70 and 1.00 as a high level of relationship, between $0.70-0.30$ as an intermediate relationship, and between 0.30-0.00 as a low-level relationship.

Value education should be given importance in order to bring individuals in multicultural personality traits. Values education to be given to the individuals from the pre-school period will enable to educate both characterwise individuals and help to acquire positive personality traits.

It has been emphasized in various studies that education is important in improving the multicultural personality traits of people in the globalizing world (Bryan and Sprague, 1997; Sheets and Chew, 2000; Polat, 2009; Demir, 2012). Therefore, it is thought that giving this education emphasis especially in the undergraduate programs will contribute positively to the development of multicultural personality.

\section{References}

Akhan, O. and A. Yalçın, 2016. The place of multicultural education in social studies curricula. Trakya University Journal of Social Sciences, $18(2): 23-46$.

Akkaya, N., 2013. The value preferences of the education faculty students (de Buca Faculty of Education). Turkish Journal of Social Research / Social Researchers Found Turkey Journal, 17(2): 69-82.

Aktay, A. and H. Ekşi, 2009. Investigation of the relationship between the value preferences of managers and teachers and organizational citizenship behaviors. Journal of Business Ethics, 2(3): 19-65.

Bacanl, H., 1999. Value preferences of university students. Journal of Theory and Practice in Education Management, 5(4): $597-610$.

Balcı, F.A. and T.Y. Yelken, 2010. It means what primary school teachers have put into the concept of value. Hacettepe Univer sity Journal of Education, 39(39): 81-90.

Balcı, F.A. and T.Y. Yelken, 2013. Values in primary school social studies program and teacher opinions on value education practices. Ahi Evran University Kırşehir Education Faculty Journal, 14(1): 195-201.

Başbay, A. and Y. Bektaş, 2009. Teaching environment and teacher competencies in the context of multiculturalism. Ege University Education and Science, 34(152): 31-43.

Başçiftçi, F., N. Güleç, T. Akdoğan and Z. Koç, 2011. Examination of the value preferences and epistemological beliefs of teacher candidates. 2nd International Conference on New Trends in Education and Their Implications, 2729.

Binat, T., 1971. National culture and morality. İstanbul: Yörük Printing House.

Bryan, S.L. and M.M. Sprague, 1997. The effect of overseas internships on early teaching experiences. The Clearing House: A Journal of Educational Strategies, Issues and Ideas, 70(4): 199-201.Available at: https://doi.org/10.1080/00098655.1997.10544196.

Bulut, C. and A. Başbay, 2014. An examination of teachers' perceptions of multicultural competence. K. Ü. Kastamonu Education Journal, 23(3): 957-978.

Büyüköztürk, Ş., 2004. Manual of data analysis for social sciences. Ankara: Pegema Publishing.

Büyüköztürk, Ş., E.K. Çakmak, Ö.E. Akgün, S.Ş. Black and F. Demirel, 2014. Scientific research methods. 18th Edn., Ankara: Pegem Academy. 
Can, A., 2014. Quantitative data analysis in the scientific research process with SPSS. 3rd Edn., Ankara: Pegem Academy.

Cengelci, T., B. Hancı and H. Karaduman, 2013. Teacher and student opinions on values education in school environment. Values Education Journal, $11(25): 33-56$.

Cirlk, İ., 2008. Multicultural education and its reflections. Hacettepe University Journal of Education, 34(34): 27-40.

Damgacı, F.K. and H. Aydın, 2013. Academician attitudes towards multicultural education. Electronic Journal of Social Sciences, 45(45): 325345.

Demir, S., 2012. Multicultural education is an important level for Erciyes university faculty members. Electronic Turkish Studies, 7(4): 14531475 .

Demircioğlu, E. and M. Özdemir, 2014. Examination of pedagogical formation students' attitudes toward multicultural education according to some variables. Ege Education Journal, 15(1): $211-232$.

Deveci, H. and A. Selanik, 2009. Values in daily life according to the diaries of elementary school students. Journal of International Social Research, 1(6): 167-181.

Dilmac, B., O.T. Aricak and S. Cesur, 2014. A validity and reliability study on the development of the values scale in Turkey. Educational Sciences: Theory and Practice, 14(5): 1661-1671.

Ercan, İ., 2001. National and universal values in primary education social studies programs. Unpublished Master Thesis, 18 March University, Canakkale.

Fergeson, L., 2008. Future worlds center. Editör. Nicoisa, Cyprus: Yiannis Laouris.

Güngör, E., 1978. Values are psychology. Amsterdam: Publications of the Turkish Association of Turkish Academicians, 8.

Güvenç, B., 2010. Human and culture. İstanbul: Boyut Publications.

Köse, E., 2015. Scientific research models. R. Y. Kıncal, (Ed.) Scientific research methods. 4th Edn., Ankara: Nobel Publishing. pp: 99-123.

Mutlu, N. and M. Öztürk, 2017. How much do we teach skills and values in social studies and history lessons? Sakarya University Journal of Education, 7(3): 552-563.Available at: 10.19126 / water.328256.

Oudenhoven, V.J.P. and V.D.K.I. Zee, 2002. Predicting multicultural effectiveness of international students: The multicultural personality questionnaire. International Journal of Intercultural Relations, 26(6): 679-694.Available at: https://doi.org/10.1016/s0147$1767(02) 00041-x$.

Özdemir, M. and K. Dil, 2013. Teachers' attitudes towards multicultural education: Case of Chanchion province. Journal of Faculty of Education, 46(2): 215.

Özensel, E., 2012. Canadian multiculturalism as a multicultural practice. Journal of Academic Inquiries, 7(1): 55-69.

Özhan, İ., 2006. Multiculturalism and multiculturalism as special aspects of differentiation. Unpublished Master Thesis. Gazi University Social Sciences Institute. Ankara.

Polat, İ. and E. Kılıç, 2013. Multicultural education and multicultural education in teacher qualifications in Turkey. YYU Journal of Education Faculty, 10(1): 352-372.

Polat, S., 2009. Personality traits of teacher candidates towards multicultural education. International Online Journal of Educational Sciences, $1(1): 154-164$.

Polat, S., 2012. School principals' attitudes towards multiculturalism. Hacettepe University Journal of Education, 42(42): $334-343$.

Sarı, E., 2005. The value preferences of prospective teachers: An example of Giresun education faculty. Journal of Values Education, 3(10): $75-90$.

Sarıçam, H., 2014. Examination of the attitudes of teacher candidates towards multicultural personality levels and multicultural education. International Symposium on Teacher Training Policy and Problems IV-ISPITE2014. Ankara Turkey.

Sheets, R.H. and L. Chew, 2000. Preparing Chinese American teacher: Implications for multicultural education. Annual Meeting of the American Educational Research Association. ERIC Digest ED 446039.

Sonmez, V. and F.G. Alacapınar, 2014. Selected scientific research methods. 3rd Edn., Ankara: Anı Publishing.

Tortop, H.S., 2014. Teacher candidates' attitudes towards gifted and multicultural education. Journal of Gifted and Talented Education and Research, 2(2): 16-26.

Turhan, M., 1972. Cultural exchange. Ankara: Prime Ministry Culture Undersecretariat Culture Publications.

Ünlü, İ. and H. Örten, 2013. Examination of perceptions of multiculturalism and multicultural education of teacher candidates. Dicle University Ziya Gökalp Education Faculty Journal, 2 1: 287-302.

Yapıcı, A. and Z.S. Zengin, 2003. A psychological research on the value preference order of the students of the faculty of theology: An example of the faculty of theology at Çukurova university. Journal of Values Education, 1(4): 173-206.

Yazıcı, S., G. Başol and G. Toprak, 2009. Teachers' multicultural educational attitudes: A study of reliability and validity. Hacettepe University Journal of Education, 37: 229-242.

Yiğittir, S. and A. Öcal, 2011. High school history teachers' views on values and values education. Karamanoğlu Mehmet Bey University Social and Economical Researches Journal, 13(20): 117-124.

Yıldırım, A. and H. Şimşek, 2008. Qualitative research in social sciences. Ankara: Seçkin Publications.

Yilmaz, E., 2009. Investigation of teachers' values preferences in terms of some variables. Values Education Journal, 7(17): 109-128. 